Polibotánica

ISSN electrónico: 2395-9525

POLIBETÁNICA

polibotanica@gmail.com

Instituto Politécnico Nacional

México

http:www.polibotanica.mx

\title{
REPORT OF A FLORAL VISITOR OF Cypripedium irapeanum (ORCHIDACEAE) IN TEPOZTLAN, MORELOS, MEXICO
}

\section{REPORTE DE UN VISITANTE FLORAL EN Cypripedium irapeanum (ORCHIDACEAE) EN TEPOZTLÁN, MORELOS, MÉXICO}

Lozano-Rodríguez, M.A.; J.L. Alanís-Méndez, and O.J. Enciso-Díaz

REPORT OF A FLORAL VISITOR OF Cypripedium irapeanum (ORCHIDACEAE) IN TEPOZTLAN, MORELOS, MEXICO.

REPORTE DE UN VISITANTE FLORAL EN Cypripedium irapeanum (ORCHIDACEAE) EN TEPOZTLÁN, MORELOS, MÉXICO.

POLIBETÁNICA

Instituto Politécnico Nacional
Núm. 46: 159-167 México. Julio 2018

DOI: $10.18387 /$ polibotanica.46.9 


\section{REPORT OF A FLORAL VISITOR OF Cypripedium irapeanum (ORCHIDACEAE) IN TEPOZTLAN, MORELOS, MEXICO}

\section{REPORTE DE UN VISITANTE FLORAL EN Cypripedium irapeanum (ORCHIDACEAE) EN TEPOZTLÁN, MORELOS, MÉXICO}

Lozano-Rodríguez, M.A.;

J.L. Alanís-Méndez, y

O.J. Enciso-Díaz

REPORT OF A FLORAL

VISITOR OF Cypripedium

irapeanum (ORCHIDACEAE)

IN TEPOZTLAN, MORELOS, MEXICO.

REPORTE DE UN

VISITANTE FLORAL EN

Cypripedium irapeanum

(ORCHIDACEAE) EN

TEPOZTLÁN, MORELOS, MÉXICO.

\section{POLIBETÁNICA}

Instituto Politécnico Nacional

Núm. 46: 159-167. Julio 2018

DOI:
M.A. Lozano-Rodríguez/miglozano@uv.mx

J.L. Alanís-Méndez

O.J. Enciso-Díaz

Facultad de Ciencias Biológicas y Agropecuarias, campus Tuxpan, Universidad Veracruzana. Carretera Tuxpan-Tampico Km. 7.5, Col. Universitaria. Tuxpan, Veracruz, México

ABSTRACT: The process and participating actors of pollination have fascinated many scholars since the time of Darwin. Nevertheless, for many species of orchids, the identity of the pollinator or the purpose of floral visits remains unknown. Cypripedium (Orchidaceae) is a genus of worldwide distribution that presents a broad range of colors and sizes. Three species are reported in Mexico: C. dickinsonianum, C. irapeanum and C. molle. However, there is very little information regarding the ecological interactions of these species. Firstly, a preliminary bibliographic review was conducted in order to compile information pertaining to the pollinators and floral visitors of the genus Cypripedium. Secondly, a population of $C$. irapeanum was monitored in a pine-oak forest at 1680 m.a.s.l. in the municipality of Tepoztlan, in Morelos, Mexico. The municipality of Tepoztlán in Morelos, Mexico, hosts a population of approximately 250 individuals of the species $C$. irapeanum. During a visit to this site in July 2015, two specimens of bees, belonging to the genus Lasioglossum subgenus Eickwortia, were found exiting from the apertures of the rear part of the $C$. irapeanum labellum. This event was photographed and one bee specimen was collected and identified to species, thus contributing to the first record of a floral visitor to this species of orchid. Lasioglossum nyctere is a floral visitor and possibly a pollinator of C. irapeanum. Future studies should confirm whether or not this bee is indeed a pollinator of the orchid.

Key words: Cypripedioideae, Hymenoptera, Lasioglossum, Orchidaceae, pollinator.

RESUMEN: El proceso de polinización y los actores que participan en ella ha fascinado a muchos estudiosos desde tiempos de Darwin. A pesar de esto, en la actualidad existen muchas especies de orquídeas de las cuales no se conoce quién es su polinizador o qué es lo que buscan en sus flores. Cypripedium (Orchidaceae), es un género que se encuentra ampliamente distribuido en nuestro planeta, con una amplia gama de colores y tamaños. Para el caso de México, se reportan tres especies: $C$. dickinsonianum, $C$. irapeanum y $C$. molle. Sin embargo, existe muy poca información sobre las interacciones ecológicas de estas especies. Primero, se realizó una revisión bibliográfica preliminar con el objetivo de compilar toda la información perteneciente a los visitantes florales y polinizadores del género Cypripedium. Segundo, se monitoreó una población de $C$. irapeanum en un bosque de pino-encino a 1680 m.s.n.m. en el municipio de Tepoztlán, Morelos. En ese sitio se encuentra una población de aproximadamente 250 ejemplares de la especie $C$. irapeanum. Durante la visita realizada en julio de 2015 se encontraron dos ejemplares de abejas pertenecientes al género Lasioglossum subgénero Eickwortia, saliendo de las aberturas de la parte trasera del labelo de $C$. irapeanum, pudiéndose capturar el momento en fotografía y colectar 
un ejemplar de las abejas que se encontraron. Hasta el momento se tiene identificada la especie de abeja encontrada, contribuyendo así al primer registro de un visitante floral para esta especie de orquídea, esperando confirmar en trabajos posteriores si es o no su polinizador.

Palabras clave: Cypripedioideae, Eickwortia, Himenóptero, Lasioglossum, polinizador.

\section{INTRODUCTION}

One of the most interesting processes of nature is pollination. It can be as simple as the pollination carried out by the wind or as complex as that carried out by the insects in orchid flowers. Pollination conducted by animals usually involves a mutualistic relationship between the animal and the plant, where the plant provides the pollinator with a reward and receives pollination services in return (Pearn, 2012). Study of pollinators of the family Orchidaceae has been of great interest to researchers; however, for many species of orchids, the identity of their pollinators remains unknown (e.g. Vanilla planifolia Andrews).

Regardless of the species of pollinators that are attracted to the flowers, these are not the only animals to be attracted by the flowers. The term "floral visitors" includes any insect that rests or alights on a flower, and visitors may or may not be actively foraging for rewards or searching for a nesting or hiding place (Nilsson 1979 as cited in Pearn, 2012) and, in some other cases, to lay eggs in the fruits of the plants. During their lifetime, from germination until pollination of their flowers, the orchids relate with many types of organism. There are many organisms that interact regularly with the orchids, e.g., the ants that often construct colonies in the roots of different species such as Oncidium sphacelatum Lindl., Epidendrum flexuosum G. Mey, Coryanthes picturata Rchb.f., among others, or in the pseudobulbs, such as those of the genus Myrmecophila. In turn, certain other organisms can also interact with the orchid flowers without necessarily pollinating them; these can be herbivorous organisms (caterpillars, crickets, slugs, etc.) or simply those that land on the flower or pass by it. It should be noted that, in some cases, these floral visitors remove pollen by accident. Effective pollination on the other hand, is carried out by those insects able to successfully remove pollen from the male sex organs of one flower and transfer it to female sex organs of another flower (Faegri and van der Pijl 1979 as cited in Pearn, 2012).

The diversity of shapes, sizes and floral structures presented by orchids allows crosspollination, i.e., the transfer of pollen between the anther of one flower and the stigma of another of the same species (Hágsater et al., 2005). In orchids of the subfamily Cypripedioide and some other genera (e.g. Coryanthes), the labellum has the shape of a bag or a bucket and forms a trap from which the pollinator can only escape through an specific route that ensures that it takes or deposits grains of pollen (Hágsater et al., 2005) and thus the pollinator transports the pollen and deposits it in another flower to subsequently repeat the process. For the genus Cypripedium, different species of pollinators have been reported, all of which are insects. In Mexico, however, only members of the family Halictidae have been reported as pollinators of C. molle Lindl. (Pérez-García \& Mó-Mó, 2014), suggesting the need to carry out more research in order to determine the pollinators of this genus in Mexico.

The genus Cypripedium comprises approximately 50 species of herbaceous plants distributed in forests and prairies, from sea level to the high mountains (J. hong Li et al., 2011). A total of 16 species are reported in North America (Cribb, 1997), with three species reported in Mexico: $C$. irapeanum La Llave \& Lex., C. molle Lindl. and C. dickinsonianum Hágsater (J. hong Li et al., 2011). Cypripedium dickinsonianum and C. irapeanum are found under the status of Subject to Special Protection and Threatened respectively, according to the NOM-ECOL-059-2010 of the Secretaria del Medio Ambiente y Recursos Naturales (SEMARNAT, 2010).

Of the three Mexican species, C. irapeanum (fig. 1) is perhaps the most studied. It is distributed from the states of Sinaloa and Durango in northwestern Mexico, through the states of the 
Transversal Neovolcanic Axis: Nayarit, Jalisco, Michoacán, Guerrero, Querétaro, Estado de México, Morelos, Puebla, Veracruz and Chiapas (Pérez-García \& Mó-Mó, 2014). Despite the wide distribution of this species in Mexico, its populations suffer from various threats such as illegal extraction, fire and land use change, among others.

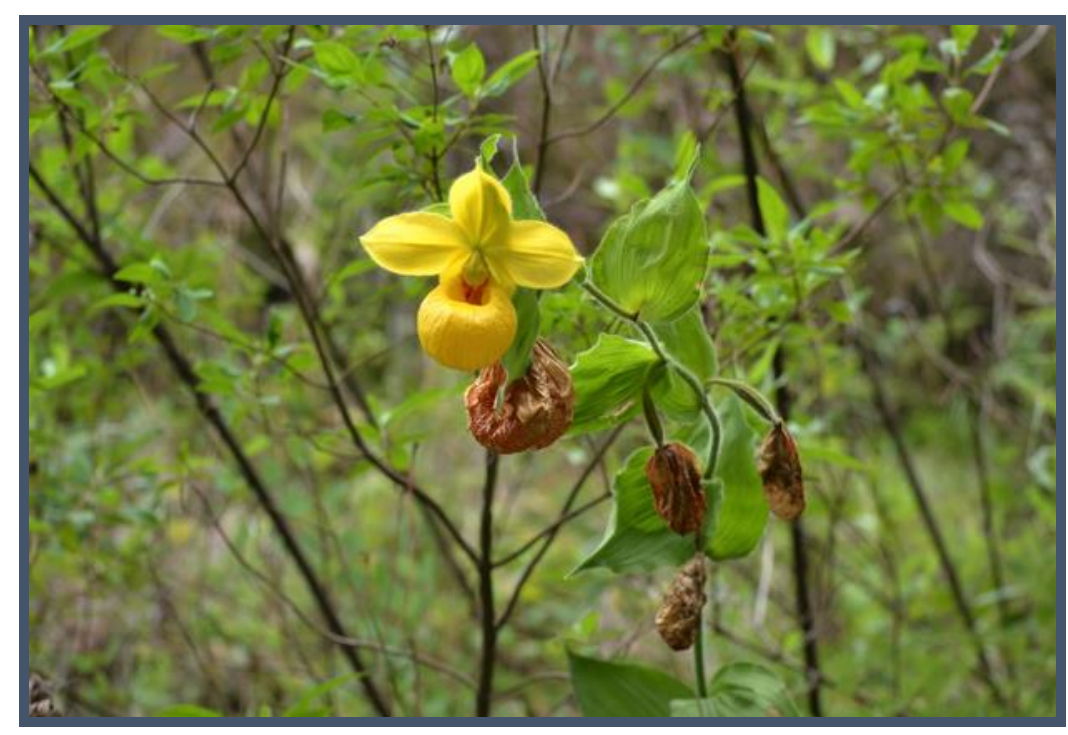

Fig. 1. Flower and fruits of Cypripedium irapeanum in its natural habitat.

According to Pérez-García \& Mó-Mó (2014), Cypripedium irapeanum (fig. 1) is a species that lives in oak and pine-oak forests, although it has been reported growing in drier sites such as semiarid scrub. Normally, it prefers open sites, even those with some disturbance. They are typical of montane environments from 1400 to 2250 m.a.s.l. but have also been found as low as 700 m.a.s.l. in Veracruz and Chiapas, and in northern Guatemala. This species can be found in both igneous and limestone substrates. It has also been found growing in substrates of metamorphic rock, possibly schists and very weathered phyllites (Pérez-García \& Mó-Mó, 2014).

\section{MATERIAL AND METHODS}

Firstly, a preliminary bibliographic review was conducted in order to compile information pertaining to the pollinators and floral visitors of the genus Cypripedium, where the identities and gender of the reported species of pollinators and floral visitors were analyzed in order to identify any preference of males or females in pollinating the Cypripedium flowers. Secondly, a population of $C$. irapeanum was monitored in a pine-oak forest at 1680 m.a.s.l. in the municipality of Tepoztlán, in Morelos, Mexico. Fifty plants were monitored from 8:00 a.m. to 6:00 p.m. Photographic images of C. irapeanum specimens were taken with a camera (Nikon D3100).

\section{RESULTS}

The population of Cypripedium irapeanum in this study is located in a transition zone of oak forest and pine forest, mainly inhabiting hillsides with slopes greater than $50^{\circ}$. Plants living between $C$. irapeanum are mainly herbs, including other orchids of the genera Bletia, Govenia and Malaxis and ferns of the genus Pteridum. Cypripedium plants can be observed growing in 
open areas reaching heights of 40 to $130 \mathrm{~cm}$, while plants growing with other herbs around them can have heights of up to $170 \mathrm{~cm}$ due to struggle for light.

The population is susceptible to forest fires, which means that there are seasons where these plants do not sprout again. However, given the anatomy, physiology and its form of life (land) of Cypripedium it means it can withstand the high temperatures of these events, opening a new mystery to its population-based study. Regarding its floral anotomy, the number of flowers produced per plant depends on the age of each of these. In large size plants, up to 8 flowers per inflorescence can be observed.

Table 1. Different species of the genus Cypripedium with their respective pollinators. ND $=$ no data.

\begin{tabular}{|c|c|c|c|}
\hline Author & Species & Pollinator & Gender \\
\hline \multirow{2}{*}{ (Antonelli et al., 2009) } & \multirow{2}{*}{ Cypripedium calceolus } & Andrena praecox & female \\
\hline & & Lasioglossum fulvicorne & female \\
\hline (Bänziger, Sun, \& Luo, 2005) & Cypripedium guttatum & Lasioglossum clypeinitens & female \\
\hline \multirow[b]{2}{*}{ (Bänziger, Sun, \& Luo, 2008) } & Cypripedium yunnanense & Lasioglossum zonulum euronotum & ND \\
\hline & Cypripedium flavum & $\begin{array}{c}\text { Andrena orchidea } \\
\text { Andrena } \mathrm{sp}\end{array}$ & ND \\
\hline \multirow{3}{*}{ (Catling, 2015) } & \multirow{3}{*}{$\begin{array}{c}\text { Cypripedium parviflorum var. } \\
\text { pubescens }\end{array}$} & Osmia proxima & $\mathrm{ND}$ \\
\hline & & Osmia albiventris & male \\
\hline & & Osmia subaustralis & female and male \\
\hline (Davis, 2015) & Cypripedium acaule & Bombus ashtoni & female (queens) \\
\hline \multirow{2}{*}{$\begin{array}{l}\text { (Ishmuratova et al. } 2006 \text { as } \\
\text { cited in Antonelli et al., 2009) }\end{array}$} & \multirow{2}{*}{ Cypripedium calceolus } & Andrena cineraria & female \\
\hline & & Colletes cunicularius & male \\
\hline $\begin{array}{l}\text { (Li, P., Luo, Y.B., Bernhardt, } \\
\text { P., Yang, X.Q. \& Kou, 2006) }\end{array}$ & Cypripedium tibeticum & $\begin{array}{c}\text { Bombus lepidus } \\
\text { B. lucorum } \\
\text { B. hypnorum } \\
\end{array}$ & female (queens) \\
\hline \multirow[t]{2}{*}{$\begin{array}{c}\text { (Peng Li, Luo, Deng, \& Kou, } \\
\text { 2008) }\end{array}$} & \multirow[t]{2}{*}{ Cypripedium plectrochilum } & $\begin{array}{l}\text { Lasioglossum viridiclaucum } \\
\text { Lasioglossum sichuanense } \\
\text { Lasioglossum sauterum } \\
\end{array}$ & female \\
\hline & & Ceratina sp. & ND \\
\hline $\begin{array}{l}\text { (P. Li, Luo, Bernhardt, Kou, } \\
\text { \& Perner, 2008) }\end{array}$ & Cypripedium henryi & Lasioglossum sauterum & female \\
\hline (J. hong Li et al., 2011) & $\begin{array}{c}\text { Cypripedium plectrochilum } \\
\text { C. arietinum }\end{array}$ & Lasioglossum spp. & ND \\
\hline \multirow{2}{*}{$\begin{array}{c}\text { (Peng Li, Pemberton, Zheng, } \\
\text { \& Luo, 2012) }\end{array}$} & Cypripedium micranthum & Scathophaga sp & female \\
\hline & Cypripedium sichuanense & Group of Drosophila immigrans & ND \\
\hline (Peng \& Yibo, 2009) & Cypripedium smithii & Bombus lepidus & ND \\
\hline $\begin{array}{l}\text { (Nilsson, } 1979 \text { as cited in } \\
\text { (Sugiura } \text { et al., 2002) }\end{array}$ & Cypripedium calceolus & Andrena haemorrhoa & female \\
\hline $\begin{array}{c}\text { (Suetsugu \& Fukushima, } \\
\text { 2014) }\end{array}$ & Cypripedium japonicum & $\begin{array}{l}\text { Bombus ardens } \\
\text { B. diversus diversus }\end{array}$ & female (queens) \\
\hline (Sugiura et al., 2002) & $\begin{array}{l}\text { Cypripedium macranthos var. } \\
\text { rebunense }\end{array}$ & Bombus pseudobaicalensis & female (queens) \\
\hline $\begin{array}{c}\text { (Zheng, Li, Pemberton, \& } \\
\text { Luo, 2011) }\end{array}$ & Cypripedium flavum & $\begin{array}{c}\text { Bombus hypnorum } \\
\text { B. remotus } \\
\text { Calliphora vomitoria }\end{array}$ & female \\
\hline $\begin{array}{l}\text { (Zhongjian, Lijun, Wenhui, } \\
\text { Liqiang, \& Yuting, 2008) }\end{array}$ & Cypripedium lentiginosum & Ferdinandea formosana & female \\
\hline
\end{tabular}


Following the review of the reports of pollinators of the genus Cypripedium, information was collated from 18 different authors report the species they studied, as well as the pollinator and, in most cases, identified the gender of these (see table 1). According to the observations made, the presence of visitors was influenced by sunlight, from 10:00 am to 3:00 p.m., was the time when the highest activity was observed, approximately 10 floral visitors. It was noted, on subsequent visits, that on cloudy days the presence of floral visitors was null. During the fieldwork conducted as part of this study, two bees of the genus Lasioglossum (Halictidae) were found within flowers of $C$. irapeanum. The bees belonged to the species Lasioglossum (Eickwortia) nyctere Vachal (fig. 2). These individuals were found within the flowers of $C$. irapeanum, and one had remains of something that looks like pollen on its thorax (fig. 3, D).

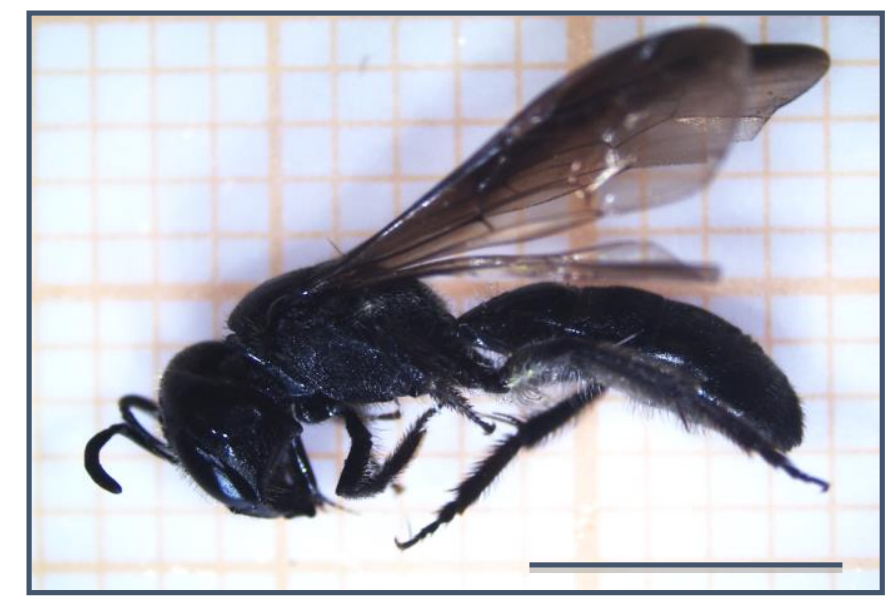

Fig. 2. Lasioglossum nyctere bee. Bar represents $1 \mathrm{~cm}$.

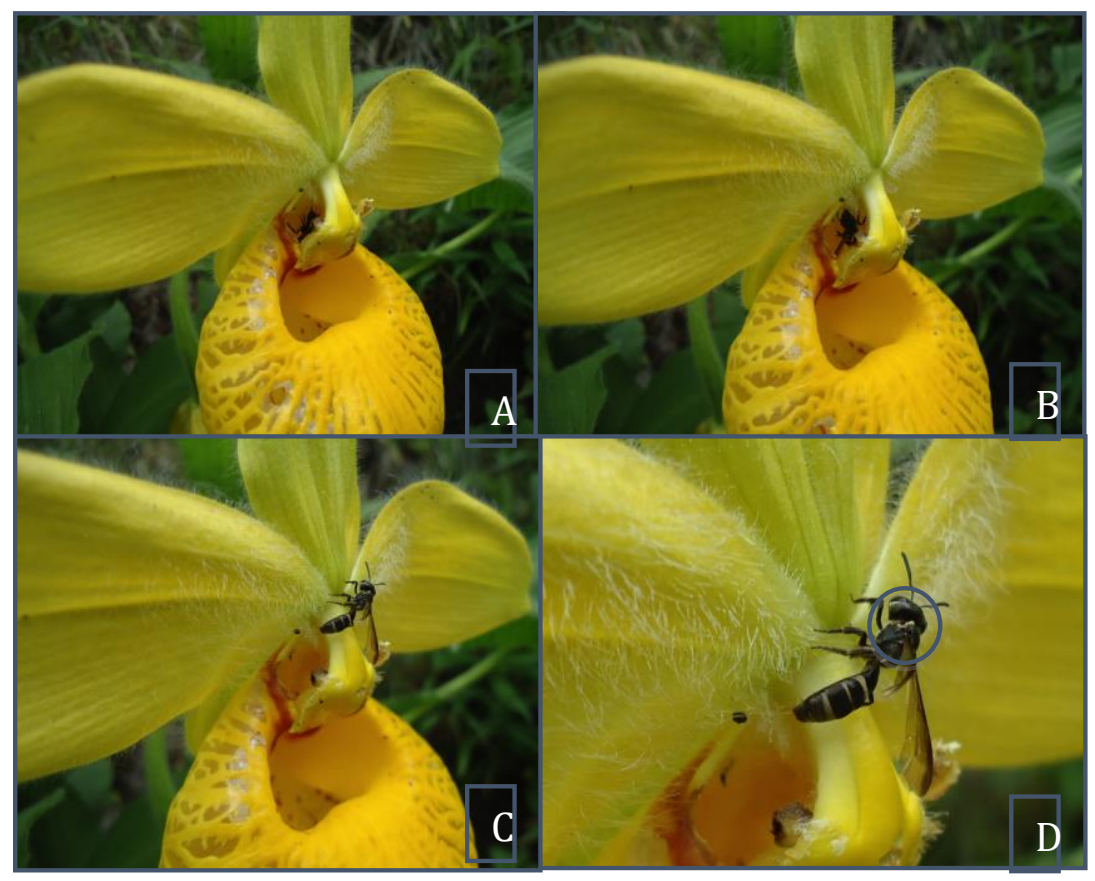

Fig. 3. A) Flower of C. irapeanum with a L. nyctere bee inside. B and C) L. nyctere leaving by the back of the labellum of $C$. irapeanum. D) Close up of $L$. nyctere leaving the flower of $C$. irapeanum with something that looks like pollen. 


\section{Discussion}

According to the bibliographic review, most of the reported Cypripedium species attract their pollinators through deception (Stoutamire 1967 as cited in Pearn, 2012), something that is very common within the family Orchidaceae. Different authors report that pollinators of the species of Cypripedium are Hymenoptera, within which the families Apidae and Halictidae are the most representative, presenting eleven and seven species of bees that pollinate Cypripedium, respectively (see table 1), also Diptera is reported as pollinator of Cypripedium orchids.

It is notable that, in most of the reports, the bees that pollinate the flowers of this genus of orchids are female, perhaps in search of a nesting site, as reported by Nilson (1979 as cited in Li, P. , Luo, Y.B., Bernhardt, P., Yang, X.Q. \& Kou, 2006) in C. calceolus, who states that the flowers generally attract pollinators through food deception (aromatic and color components, false nectar guides), as well as appearing to present a suitable nesting site (aroma and cavity).

It is interesting to mention the case of Cypripedium plectrochilum and C. arietinum that, despite being species that are completely separated geographically (East Asia and North America, respectively) (J. hong Li et al., 2011), are apparently both pollinated exclusively by bees of the same large (ca. 1100 species) and pandemic genus, Lasioglossum (Peng Li et al., 2008), of the family Halictidae. Likewise, Pérez-García \& Mó-Mó (2014), state that the pollinators of the species $C$. molle are bees of the same family (Halictidae), although no specific genus or species of pollinator has been identified.

The bees observed in this study belonged to the same genus in which are included the species reported by Antonelli et al. (2009), Bänziger et al. (2005), Bänziger et al. (2008), P. Li et al. (2008), Peng Li et al. (2008), and J. hong Li et al. (2011) as pollinators of other species of Cypripedium. The specimen collected is a female, coinciding with that reported by Antonelli et al. (2009), Bänziger et al. (2005), P. Li et al. (2008), Peng Li et al. (2008), and J. hong Li et al. (2011). Possibly Lasioglossum nyctere visit the flowers of $C$. irapeanum in search of a nest and when it enters the labellum and it's trapped it passes through the back of the labellum and removes the pollen from the anther (fig. 3), when visiting another flower, it deposits the pollen in the stigma, carrying out the pollination. It should be mentioned that the subfamily of Cypripedioideae is characterized by having pollen in the form of undefined masses, contrary to the subfamilies of Epidendroideae and Orchidoideae where pollen is found in the form of pollinia. The pollen produced by $C$. irapeanum can be disintegrated in small masses that adhere to the pollinators, as seen in figure 3, D. It is very interesting that the genus Lasioglossum appears as a floral visitor in Cypripedium irapeanum because as reported by $\mathrm{J}$. hong Li et al. (2011) Lasioglossum is the genus that visit other European and Asiatic species (C. calceollus, C. guttatum, $C$. yunnanense, $C$. plectrochilum) considering the geographic distance that exists between them.

Lasioglossum nyctere is a bee of the subgenus Eickwortia, which comprises only three species distributed in Mexico and Central America (Gibbs \& Dumesh, 2013). According to Gibbs \& Dumesh (2013) and Pérez-García \& Mó-Mó (2014), the distribution patterns of L. nyctere and C. irapeanum within the Mexican territory mostly coincide, which supports the suggestion that this bee species may be one of the possible pollinators of the orchid.

\section{CONCLUSIONS}

Lasioglossum nyctere is a floral visitor and is possibly the pollinator of C. irapeanum (fig. 3), considering the relation to the fact that Lasioglossum is one of the genera recorded as pollinating other species of Cypripedium. It should be noted that this is the first report of a floral visitor found in C. irapeanum. It is necessary to conduct further fieldwork focused on the search for floral visitors in C. irapeanum in order to prove whether L. nyctere is in fact its 
pollinator, or simply a floral visitor. There remains the possibility that other species of bees may visit and/or pollinate $C$. irapeanum.

\section{ACKNOWLEDGEMENTS}

The authors would like to thank doctor Ismael Hinojosa of the Instituto de Biología of UNAM, for identification of the Lasioglossum nyctere specimen collected.

\section{LITERATURE CITED}

Antonelli, A., Dahlberg, C. J., Carlgren, K. H. I., \& Appelqvist, T. (2009). Pollination of the lady's slipper orchid (cypripedium calceolus)in scandinavia - Taxonomic and conservational aspects. Nordic Journal of Botany, 27(4), 266-273. https://doi.org/10.1111/j.1756-1051.2009.00263.x

Bänziger, H., Sun, H., \& Luo, Y. B. (2005). Pollination of a slippery lady slipper orchid in south-west China: Cypripedium guttatum (Orchidaceae). Botanical Journal of the Linnean Society, 148(3), 251-264. https://doi.org/10.1111/j.1095-8339.2005.00400.x

Bänziger, H., Sun, H., \& Luo, Y. B. (2008). Pollination of wild lady slipper orchids Cypripedium yunnanense and C. flavum (Orchidaceae) in south-west China: Why are there no hybrids? Botanical Journal of the Linnean Society, 156(1), 51-64. https://doi.org/10.1111/j.1095-8339.2007.00755.x

Catling, P. M. (2015). Osmia species (Megachilidae) Pollinate Cypripedium parviflorum (Orchidaceae) and Packera paupercula (Asteraceae): A Localized Case of Batesian Mimicry? Canadian Field-Naturalist, 129(1), 38-44.

Cribb, P. (1997). The Genus Cypripedium. USA: Timber Press.

Davis, R. W. (2015). THE POLLINATION BIOLOGY OF CYPRIPEDIUM ACAULE (ORCHIDACEAE) Linked references are available on JSTOR for this article:, 88(856), 445-450.

Gibbs, J., \& Dumesh, S. (2013). A new species, Lasioglossum (Eickwortia) hienae, from Mexico (Apoidea: Halictidae). Journal of Melittology, (13), 1. https://doi.org/10.17161/jom.v0i13.4518

Hágsater, E., Soto Arenas, M. A., Salazar Chávez, G. A., Jímenez Machorro, R., López Rosas, M. A., \& Dressler, R. L. (2005). Las orquídeas de México. México: Instituto Chinoín.

Li, P. , Luo, Y.B., Bernhardt, P., Yang, X.Q. \& Kou, Y. (2006). Deceptive pollination of the Lady's Slipper Cypripedium tibeticum (Orchidaceae). Plant Systematics and Evolution, 262(1), 53-63. https://doi.org/10.1007/s00606-006-0456-3

Li, J. hong, Liu, Z. jian, Salazar, G. A., Bernhardt, P., Perner, H., Tomohisa, Y., ... Luo, Y. bo. (2011a). Molecular phylogeny of Cypripedium (Orchidaceae: Cypripedioideae) inferred from multiple nuclear and chloroplast regions. Molecular Phylogenetics and Evolution, 61(2), 308-320. https://doi.org/10.1016/j.ympev.2011.06.006

Li, J. hong, Liu, Z. jian, Salazar, G. A., Bernhardt, P., Perner, H., Tomohisa, Y., ... Luo, Y. bo. (2011b). Molecular phylogeny of Cypripedium (Orchidaceae: Cypripedioideae) inferred from multiple nuclear and chloroplast regions. Molecular Phylogenetics and Evolution, 61(2), 308-320. https://doi.org/10.1016/j.ympev.2011.06.006

Li, P., Luo, Y. B., Deng, Y. X., \& Kou, Y. (2008). Pollination of the lady's slipper Cypripedium henryi Rolfe (Orchidaceae). Botanical Journal of the Linnean Society, 156(4), 491-499. https://doi.org/10.1111/j.1095-8339.2007.00767.x

Li, P., Luo, Y., Bernhardt, P., Kou, Y., \& Perner, H. (2008). Pollination of Cypripedium plectrochilum (Orchidaceae) by Lasioglossum spp. (Halictidae): The roles of generalist attractants versus restrictive floral architecture. Plant Biology, 10(2), 220-230. https://doi.org/10.1111/j.1438-8677.2007.00020.x 


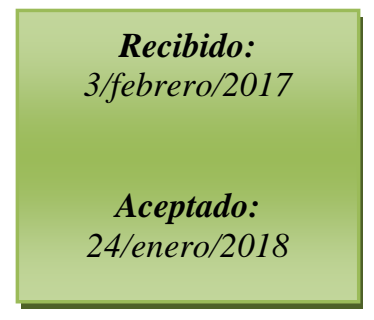

Li, P., Pemberton, R., Zheng, G., \& Luo, Y. (2012). Fly pollination in Cypripedium: A case study of sympatric $C$. sichuanense and C. micranthum. Botanical Journal of the Linnean Society, 170, 50-58. https://doi.org/10.1111/j.1095-8339.2012.01259.x

Pearn, M. (2012). Pollination and Comparative Reproductive Success of Lady'S Slipper Orchids Cypripedium Candidum, C. Parviflorum, and Their Hybrids in Southern Manitoba. https://doi.org/10.1017/CBO9781107415324.004

Peng, L., \& Yibo, L. (2009). Reproductive biology of an endemic orchid Cypripedium smithii in China and reproductive isolation between C.smithii and C.tibeticum. Biodiversity Science, 17(4), 406. https://doi.org/10.3724/SP.J.1003.2009.09046

Pérez-García, E., \& Mó-Mó, E. (2014). Die Cypripedioideae von Mesoamerika. Teil 1a Cypripedium. Die Orchidee, 65(6), 476-482.

SEMARNAT. (2010). Nom-059-Semarnat-2010. Diario Oficial de La Federación, 78. Retrieved from http://www.dof.gob.mx/normasOficiales/4254/semarnat/semarnat.htm

Suetsugu, K., \& Fukushima, S. (2014). Pollination biology of the endangered orchid Cypripedium japonicum in a fragmented forest of Japan. Plant Species Biology, 29(3), 294-299. https://doi.org/10.1111/1442-1984.12016

Sugiura, N., Goubara, M., Kitamura, K., \& Inoue, K. (2002). Bumblebee pollination of Cypripedium macranthos var. rebunense (Orchidaceae); a possible case of floral mimicry of Pedicularis schistostegia (Orobanchaceae). Plant Systematics and Evolution, 235(1-4), 189-195. https://doi.org/10.1007/s00606-002-0229-6

Zheng, G., Li, P., Pemberton, R., \& Luo, Y. (2011). Mixed bumblebee and blowfly pollination of Cypripedium flavum (Orchidaceae) in Sichuan, China. Ecological Research, 26(2), 453-459. https://doi.org/10.1007/s11284-010-0798-8

Zhongjian, L., Lijun, C., Wenhui, R., Liqiang, L., \& Yuting, Z. (2008). Correlation between numerical dynamics and reproductive behavior in Cypripedium lentiginosum. Acta Ecologica Sinica, 28(1), 111-121. https://doi.org/10.1016/S1872-2032(08)60021-9 